\title{
The Returns to Occupations: The Role of Minimum Wage and Gender in Nigeria
}

\begin{abstract}
This paper examines the economic returns to being employers, paid workers and self-employed own account individuals in a lower middle income economy using quantile regressions while accounting for selection using Heckman selection models. The results suggest that although the majority of employers experience labour wage premiums throughout the income distribution, self-employed own account individuals experience a wage penalty at the lower quantiles of the income distribution where paid workers reap benefits from minimum wage guarantees, suggesting that minimum wage legislations may push individuals with low skills into selfemployment. Furthermore, female employers and paid workers tend to be relatively well educated implying that education enables females to escape the job glass ceiling although males typically earn significantly more than females.
\end{abstract}

Keywords: Entrepreneurship; Occupational Choice; Wages; Gender; Nigeria; Africa

JEL Classification Codes: L26, J24, E24, J16, J21, J46 


\section{Introduction}

The wage differential between occupational groups is a topic of remarkable scholarly interest, particularly with regard to the contrast between self-employed individuals and employees (Acs et al., 2016, Tamvada 2010). Belonging to an occupational category can result in income premiums or penalties as individuals seek to maximise expected utility by opting for an employment option that gives the greatest economic returns based on their human capital. The occupational choice however can be constrained by external factors such as minimum wage regulations, and social norms such as those related to gender.

The occupational decision-making has been thoroughly investigated for developed countries (Acs et al., 2016; Carmona, Congregado, Golpe, \& Iglesias, 2016). An emerging body of research suggests that self-employed individuals represent two-thirds of economically active population of the developing world (Gindling \& Newhouse, 2014). Self-employment is a compelling choice for both the new entrants into the labour market as well as the unemployed in Less Developed Countries (LDC's) (Maloney, 2003; Rees \& Shah, 1986). However, the large body of self-employment literature (see Parker (2009), for a survey) has treated self-employed individuals as a homogeneous group. In contrast to this view, recent studies suggest that selfemployed individuals in developing countries are a heterogeneous group consisting of highly qualified professionals as well as individuals choosing self-employment out of necessity (Maloney 2003; Tamvada 2010; Günther \& Launov 2012; Fields 2013, Gindling \& Newhouse 2014).

Nevertheless, the literature rarely examines the nature of income distribution across these heterogeneous self-employed groups, and the relative positioning of self-employed individuals' 
income with respect to other occupational categories. ${ }^{1}$ This paper provides a novel approach to resolve these compelling questions by analysing the returns to self-employment across the income distribution, distinguishing between narrowly defined self-employed "own account" workers and employers, in the emerging market economy context.

We make several contributions using data from Nigeria. Firstly, by separating employers from self-employed own-account workers, and by examining the returns across the distribution using quantile regressions, we provide a more nuanced picture of the heterogeneity within selfemployment and entrepreneurship. Secondly, by examining economic returns to occupations though the lens of gender, we provide novel insights into heterogeneity in economic returns to self-employment that are driven by culture. Thirdly, we examine the role of institutional characteristics for labour outcomes in a developing economy by underscoring the role of minimum wage legislation for occupational selection and subsequent economic returns, an area of research that has received little attention in the occupational choice and self-employment literature in the context of emerging market economies. Finally, we open a new line of research on self-employment in Africa's largest economy, Nigeria, offering policy implications.

Our results suggest that employers of labour tend to experience labour wage premiums throughout the labour wage distribution, demonstrating that self-employed individuals and employers who employ others are two distinct occupational categories with widely different levels of economic returns. In contrast to this, at the lower end of the income distribution, there is a nuanced labour income penalty for self-employed individuals, while paid workers reap the benefits of minimum wage guarantees. Furthermore, we discover that although there are more

${ }^{1}$ Tamvada (2010) examines self-employment welfare using consumption measures in the absence of income data for the Indian context. 
male employers, female employers tend to be relatively more educated than male employers although males typically earn significantly more than females.

The rest of the paper is organized as follows. The next section discusses the nature of selfemployment in a developing country environment. The third section presents the Nigerian country context of this study. The fourth presents the data and the empirical methodology used. The fifth section discusses the results while the final section provides implications and concludes.

\section{Theoretical Background}

The seminal Harris and Todaro (1970) model assumes that the self-employed are worse-off in the labour wage hierarchy relative to paid workers in developing countries (Fields, 2013). Indeed a plethora of empirical studies seem to point in this direction (Bosch \& Maloney, 2010) and the literature on developing countries traditionally classifies the self-employed as a distressed residual group of workers, rationed out of formal sector jobs, reporting lower labour wages compared to paid workers (Gindling \& Newhouse, 2014). Negative earnings premium for selfemployment in developing countries were found for example by Jhabvala, Sudarshan, and Unni (2003) in India and by Gong and Van Soest (2002) in Mexico.

However, recent studies have shown that some self-employed individuals may be advantaged for non-pecuniary motives (Maloney, 2003; 2004), and purely monetary reasons (Mohapatra, Rozelle, \& Goodhue, 2007; Yamada, 1996). For example, Cunningham and Maloney (2001) suggest that there are six clusters of the self-employed individuals in Mexico, and two of the 
self-employed clusters were actually advantaged compared to paid workers while others were not. An informative distinction is made by Tamvada (2010), who suggests that Indian selfemployed individuals with employees have significantly greater economic returns than both salaried employees and self-employed individuals without employees in terms of household consumption.

These results operationalize two distinct parts of the self-employment sector, an "upper" and "lower" tier (Fields 2004). The upper tier consists of individuals who voluntarily enter this sector because, given their characteristics, they expect to earn more in the self-employment sector than they would earn in the paid sector; while the lower tier is made up of individuals who expect to earn little in self-employment, but have no choice but to persist.

Webb et al. (2014) discuss the myriad activities that fall within the boundaries of the informal economy and distinguish between the institutional foundations of informality in developed versus developing economies. This has implications for our study as entrepreneurial activities differ in lesser developed contexts characterized by formal institutional voids compared to developed contexts (e.g., lack of property rights, contract law, utilities, transportation, and communication infrastructures) and so entrepreneurs might have to rely on more informally construed structures in developing economies (Khanna, Palepu, \& Sinha, 2005; Khanna \& Palepu, 2013).

Furthermore, we recognize that gender differences driven by social norms might exist for occupational statuses. For example, Boden Jr (1996) reports that women are more likely than men to shoulder family-related obligations, especially child rearing: and there is evidence that this affects the female propensity to become self-employed. In addition, women might 
experience some bias in paid employment (commonly called a "glass ceiling"), and gender inequality in terms of earnings has also been documented (Hughes, 2003). Hundley (2000) investigated the earnings gap associated with self-employment and reported that self-employed male earnings increased with marriage and family size. The author reported that women tended to be self-employed to facilitate household production while men tended towards selfemployment to achieve higher earnings (males being traditionally viewed as breadwinners). Wellington (2006) also, suggested that married women with greater family responsibilities were more likely to be self-employed.

These social distinctions may be even stronger in developing countries, there might be some strong perceptions of gender roles for women and perhaps a cultural bias against women in formal paid employment which might 'push' females once again into self-employment. In our country of study - Nigeria, it is reported that only one third of its labour force are women, and although women occupy about 30 percent of all posts in the public sector, they only occupy 17 percent of senior positions. Women at every educational level also earn less than their male counterparts (BritishCouncil, 2012a). While there are no gender-specific laws in Nigeria, the inequalities are most notable in the formal sector representation for women in the country. Women are also five times less likely to own land, despite accounting for 70 percent of the rural labour force, and the haphazard application of the "Sharia Law" in some northern states of the country might affect women even more (BritishCouncil, 2012a).

The literature also indicates that there can be significant distributional disparities especially within lower and middle income nations (Palma, 2011). Nigeria is a lower middle income country with a gini coefficient 48.8, which indicates significant inequalities (World Bank, 2016). 
Nigeria is also a highly entrepreneurial economy and therefore not only offers attractive opportunities in the entrepreneurial employer sector of the job market, but represents social norms, where those opportunities are more likely to be recognised and taken, implying the potential for high returns from self-employment, that may be more difficult to detect elsewhere.

More generally, following a long-standing bias in development literature, institutional settings have received little attention (Easterly, 2013), and that includes cultural norms supporting entrepreneurship we just discussed. However, institutional settings are important for explaining income distributions. In this paper, we also pay attention to one well-defined characteristic of the formal institutional system which is highly relevant to the labour market, the minimum wage. The literature on minimum wage in developing countries is inconclusive but recent evidence suggests that raising the minimum wage could increase or decrease poverty, depending on labour market characteristics (Lemos, 2009).

Pertinent to our inquiry, Gindling (2014) reports that if job losses in the formal sector are small, raising the minimum wage is likely to reduce poverty and if informal sector wages rise when the minimum wage increases, higher minimum wages are also likely to reduce poverty. However, if higher minimum wages cause workers to lose formal sector salaried jobs and if minimum wage legislation does not cover a large pool of informal workers such as in the case of Nigeria, higher minimum wages are not likely to reduce poverty. 


\section{Context}

With a population of about 177.5 million people, Nigeria is currently the most populous country in Africa; it was classified as a lower-middle-income country at the time the data used in this research were collected and that classification has not changed (World Bank, 2016). It is the largest economy in Africa and is also the biggest oil exporter on the continent with the continents' largest natural gas reserves. About 66 percent of the Nigerian population are active in the labour force (NBS, 2014).

\subsection{Entrepreneurship In Nigeria}

According to World Bank estimates during our period of study, 44.8 percent of the Nigerian labour force worked in agriculture, 13.5 percent in industry, and 41.7 percent in services. A significant majority, consisting of about 70.9 percent of men and 74.8 percent of women in the economically active group reported being self-employed (SLOAN, 2014). From 2003 - 2008, Nigeria set out an ambitious reforms program; the most important element of the program is to base the budget on a conservative reference price for oil, with the excess saved in a special 'Excess Crude Account' (ECA) because there are concerns that the economy is over reliant on revenue from oil. Following these measures, the economy responded with strong growth between 2003 to 2010, and our study falls within this period (World Bank, 2015). However, during that time, Nigeria also continued to have a less favourable profile in terms of poverty, government corruption, illiteracy and poor infrastructure (NBS, 2014; World Bank, 2015).

Regarding self-employment, indices from the Nigerian Global Entrepreneurship Monitor (GEM) survey suggest that 68 percent of male entrepreneurs and 63 percent female entrepreneurs are 
opportunity entrepreneurs, while the remaining are necessity entrepreneurs (Bosma \& Levie, 2010). Traditional labour theories e.g. the Harris and Todaro (1970) and Fei and Ranis (1964) models we already mentioned suggest that Nigeria should have a higher level of necessity driven entrepreneurship given its relatively low GDP per capita. However, GEM reports indicate that it has a higher opportunity entrepreneurship rate than many developed countries with significantly greater GDPs. This disparity may be explained by the insufficient attention being paid in traditional development literature to both culture as already mentioned, and to institutions (Easterly, 2013). As argued by Du and Mickiewicz (2016), entrepreneurship may thrive under a non-transparent government, but not under a predatory governance regime. Despite its shortcomings and high level of corruption, Nigeria cannot be classified as having a "predatory government" as it does not have policies that specifically pillage entrepreneurs as understood by Tocqueville (1840/2003: 285).

\subsection{Entrepreneurship and Institutions in Nigeria}

Unless we stress the significance of political institutions and culture, the high proportion of opportunity entrepreneurs may appear puzzling in Nigeria, as Doing Business (DB) ranked Nigeria $147^{\text {th }}$ out of 189 countries in its index; it also ranked the country $122^{\text {nd }}$ in ease to start a business. However, this low score was primarily due to the low scores on electricity supply and registering property; the country placed 185 out of 189 in both instances. According to data collected by DB, starting a registered business in Nigeria requires 8 procedures, takes 28.0 days, and costs 58.3 percent of the nation's income per capita. It is therefore not surprising that the 
informal sector in Nigeria consisting of unregistered businesses is quite substantial (DoingBusiness, 2014).

While informality may become a constraint on the size and growth of businesses (De Soto, 1989), it is not in itself the major barrier to entrepreneurship especially if entrepreneurship is supported by favourable social norms. For example, research from Nigeria has highlighted how organizations adopt informal rules and identify ambiguity of formal institutions as a major source of organizational defiance (Decker, 2007; Uzo \& Mair, 2014).

Finally, there are compelling reasons to argue that both types of self-employment (push and pulled) are likely to co-exist in Nigeria. High poverty and unemployment rates could serve as push factors forcing people into self-employment; while perceived opportunities, like both (1) deficiencies in the infrastructure that can be exploited by would be entrepreneurs and (2) opportunities triggered by the high economic growth rates, could serve as a catalyst for pulling individuals into self-employment (Parker, 2009).

\subsection{The Minimum Wage Regulation in Nigeria}

Nevertheless, while some regulations may have less impact, we would expect those directly related to labour markets to matter. The minimum wage is a regulatory dimension we wish to consider in more detail. Its current level is $\$ 18,000^{2}$ monthly (Eighteen thousand Naira) in Nigeria (equivalent to roughly $\$ 113$ monthly at the time of writing), and it is generally enforced across the country. Enacted by the National assembly of the Federal Republic of Nigeria, the

\footnotetext{
${ }^{2}$ The exchange rate was approximately $\$ 1: \$ 158$.
} 
minimum wage act covers both the public and private sector of Nigeria (The National Minimum Wage Act Cap. N61 Laws of the Federation of Nigeria, 2004).

It also covers workers at federal, state and local government levels (NBS, 2014). It has implications for labour market decisions as individuals could accept the minimum wage instead of venturing into self-employment because incomes in self-employment can be volatile and uncertain, but as other regulatory features it does not restrict entrepreneurship in a substantive way. At the same time, the Nigerian government does not provide any unemployment benefits to unemployed or disabled people, which taken together may generate necessity driven entry into self-employment at the low end of the spectrum.

One possible explanation of the paradox of high level of entrepreneurship in Nigeria despite regulatory barriers has been hinted at above: since the end of military rule in 1999, Nigeria does not have a predatory government, social norms promote entrepreneurship the country and enjoys relatively effective constraints on the executive (Polity 4, 2017). These higher order constitutional features have a significant impact on entrepreneurship, compared with the impact of lower level regulations as captured by DB indices (Estrin, Korosteleva, \& Mickiewicz, 2013). Similarly, to some extent, private entrepreneurs aim to fill voids resulting from government ineptitude, by providing amenities and services in terms of housing, medical services, agriculture, education, security and power generation. For example, Nigeria was recently reported as the world's largest importer of private generators by The Economist because there is a huge void in electricity generation. The extant literature has also clearly highlighted the large informal economy in Nigeria and sizable infrastructural deficits existing in the country (Russ et al.,2017; Meagher, 2016). 


\subsection{Gender and Occupation in Nigeria}

However informal institutions and social attitudes while generally supportive to entrepreneurship, may also have negative impact in some respects. In particular, while the Nigerian constitution prohibits discrimination on the grounds of gender, this is not universally enforced, and customary and religious laws restrict women's rights (British Council, 2012b). There are also regional differences in Nigeria that might be interesting to investigate (Ehrhardt, 2017). For example, some interpretations of Sharia and customary laws, prevalent especially in the North of the country, restrict freedom of movement, marriage and inheritance for women. In addition to these, Nigeria has large gender gaps in education, economic empowerment, income, and political participation (OECD, 2014). For these reasons, we need to examine the selfemployment profile from a gender perspective in the Nigerian context.

The gender debate is very pertinent because women might be unable to participate fully in the labour market because they are required to combine their household activities with income yielding jobs. For example, research from India, a country with similar gender characteristics as Nigeria has found that constrained choice, limited contacts of women and physical segmentation

of the labour market perpetuate forces that entrap women workers in a low-income situation with worse outcomes than those of their male counterparts (Mitra, 2005).

While the focus above is on opportunity driven entrepreneurship, individuals can be pushed into self-employment either by unemployment or other negative factors. This can also be said to be the case in many developing countries (Fields, 2013; Gindling \& Newhouse, 2014; W.F. Maloney, 2004). As opportunity driven self-employment is likely to be associated with a higher income and necessity driven self-employment with a lower income, the paper examines the 
returns to occupations across the income distribution to investigate if self-employed individuals experience wages penalties when compared to employers and paid workers.

\subsection{Research Questions}

Guided by the gaps in the literature and given the context, this paper examines the nature of income distribution across self-employed groups, and the relative positioning of self-employed individuals' income with respect to other occupational categories. The central questions answered by this paper are: (i) Are the self-employed likely to experience income premiums or penalties when compared to paid workers? (ii) Does the minimum wage have any implications for self-employed and paid workers? (iii) Are there distinguishable patterns among occupational status and gender in this context? We hypothesize that given the occupational structure of individuals typical in low income and lower middle income countries and exemplified in Nigeria, interesting insights can be derived by examining the income returns to employment across the income distribution.

\section{Data and Methods}

The database used for this analysis is from the Nigerian Living Standards Survey (NLSS) otherwise known as the Living Standards Measurement Survey (LSMS) for the year 2004. The NLSS is an extensive micro-level household survey detailed in its coverage of various topics; it provides a solid basis for an in-depth analysis of households and individuals in the country. The survey was conducted by the Nigerian Bureau of Statistics (NBS), a body that has received 
support from the World Bank. The data covers both rural and urban areas of all the 36 states of Nigeria and the Federal Capital Territory.

To encourage full disclosure, respondents were assured that their responses would be used for research, planning and statistical purposes alone and not for taxation. In line with the extant literature, the final sample is restricted to the individuals between the ages of 16 and 65 (representing the legal working age within the country). Individuals employed in the agricultural sector are removed from the sample, as well as retired persons and full time students (Gindling \& Newhouse, 2014; Parker, 2009).

The final database consists of 18,397 individuals (10,206 males and 8,191 females) and covers the entire country. As expected from official reports, most economically active individuals are self-employed "own account" individuals (self-employed without workers). The next largest category are paid workers (wage workers) and the smallest employed group are the employers (self-employed with workers). All the information and descriptive statistics pertaining to the variables used in our empirical analyses are available in the online appendices section.

Our descriptive statistics demonstrate that employers have the highest annual labour wages, followed by paid-employees and self-employed own account individuals. The labour wage earning sample in the survey consists of a total of 10,832 respondents made up of 605 employers, 3,669 paid workers and 6,558 self-employed individuals who reported labour wages ranging from ${ }^{3} \$ 36,000$ to $\$ 2,160,000$ annually which implies a wage range of $\$ 3,000$ to $\$ 180,000$ monthly. It also appears that males always earn more than females except in few cases: interestingly, female employers in the survey earn more on average than male employers when

\footnotetext{
${ }^{3}$ The exchange rate was $\$ 1: \$ 158$ at the time of writing.
} 
individual characteristics have not been controlled for. The labour wage and employment statistics are also in line with macro-indicators given by the World Bank (2015) and NBS (2014), in terms of regional and gender differences in employment within the country (Olarewaju, 2016). We use all the variables that are available to us from the survey and perform detailed robustness checks that are available on request.

\subsection{Methodology}

First, to investigate the income differential relationship, this paper makes use of two techniques. We start with the Heckman (1979) model and estimate the conditional annual labour wage (income) amongst occupations, taking into account labour force participation. Next, we utilize quantile regressions as they compute several different regression curves corresponding to the various percentage points on the labour wage distribution, thus giving a more complete picture of the wage spectrum and enabling us to distinguish between low-value-added and high-valueadded activities as implied by achieved income.

Our motivation to apply the Heckman selection model is to note that people who work are selected non-randomly from the population; we have access to annual income observations only for those who work and estimating the determinants of wages from the subpopulation who work may thus introduce a selection bias. The Heckman correction solves this potential selection bias by first estimating the probability of working and then estimating the annual income. In all our estimations, we can denote annual income and explanatory variables comprising standard human capital formation literature variables such as age, sector, gender, marital status, educational attainment, ability to speak a Nigerian language, region and credit constraints. The estimated 
coefficients are thus interpreted as a measure of the conditional earnings premium/penalty experienced by the self-employed and employers respectively compared to paid wage earners.

This paper also makes use of quantile regressions in addition to Heckman estimates to calculate self-employment own account and employer premiums/penalties conditional on observable individual characteristics. We do this because while the Heckman selection based regression coefficients give a grand summary of averages in the distribution, quantile regressions offer additional insights since we can compute several different sets of coefficients corresponding to various percentage points specified, thus giving a more complete picture of the wage distribution (Koenker and Hallock, 2001).

The quantile regression allows us to determine if individuals in any of the employment states are bound to experience a labour wage/income premium or penalty relative to another employment option, as evaluated at different points on the labour income distribution. For example workers at the lower income levels might have a different experience compared to workers at the higher income levels. All our equations are available in the online appendices section. Our results are presented in the next section.

\section{Results and Discussion}

All our tables and figures are available in the online appendices section as we restrict our discussion in this text to what is comprehensible to a general reader. Our results indicate that self-employed own account individuals earn about 16 percent less than wage workers, while employers earn about 12.6 percent more than wage workers. The quantile regressions suggest a distinct pattern with self-employed own account individuals consistently earning less than paid 
employees until the upper end of the income spectrum. Crucially, the labour wage differential between paid workers and self-employed own account workers steadily increases at the lower end of the income spectrum until where the minimum wage of $\$ 18,000$ is. After this point, the labour wage differential starts to reduce steadily with the differences in earnings disappearing at the top most quantiles. Throughout the earnings distribution, employers have the highest earnings.

Our results are consistent with the extant literature (Fields, 2013; Gindling \& Newhouse, 2014; Günther \& Launov, 2012) suggesting that self-employed individuals are a heterogeneous group, with employers having significantly more economic returns than self-employed own account individuals. Employers have significant earnings premiums and do better than paid workers and self-employed own account individuals throughout the income distribution, and hence we can conjecture they are mostly engaged in pulled (opportunity-driven) self-employment if only monetary indicators are considered. In contrast, self-employed own account individuals are worse off in terms of labour wage until the upper end of the income spectrum, however from that point onwards they begin to have earnings comparable with employers and paid workers.

In examining the impact of occupational choice on wages for men and women, we estimate our model for men and women separately. The results suggest that both male and female employers experience income premiums and do better than paid workers and self-employed own account individuals for most part of the income distribution until the upper quantiles. The labour wage penalty for self-employed "own-account" workers occurs up to a certain point on the labour wage distribution and then starts to improve. This cut-off point is the $10^{\text {th }}$ percentile for men, and interestingly a higher threshold of the $20^{\text {th }}$ percentile for women, consistent with what we already 
discussed regarding minimum wage; as self-employed individuals are not guaranteed minimum wages, they appear to be worse off towards the lower end of the distribution.

Our results in sum show that the labour wage penalty for self-employed own account individuals is found towards the lower end of the distribution where paid workers enjoy some minimum wage guarantee; this amount has been reviewed several times but is currently $\$ 18,000$ monthly. The trend is for the labour wage penalty to progressively increase up to the minimum wage level point between the $10^{\text {th }}$ and $20^{\text {th }}$ percentiles and then improve later as this effect wears off. This finding is significant and robust, and in the absence of other economic reasoning, this may indicate two things: (1) that potential workers who cannot receive employment at minimum wage are displaced towards low income self-employment as they cannot legally be hired below minimum wage, (2) that these individuals are special in the sense that they cannot even attain a job that provides the minimum wage, which is subsequently reflected in the fact that they are penalized.

As the World Bank, NBS and other data providing bodies have highlighted significant regional differences in Nigeria, we examine the robustness of the results for different regions (also included in our regressions). Thus, we recreate our model for each of the four regions in Nigeria (the North, Mid-belt, South-East and South-West). The results are robust, and consistently show that self-employed own account individuals are worse off in terms of labour wages in all the four regions and that due to the fact that self-employed individuals are not guaranteed minimum wages in the manner already described.

Results from our classification tests also imply that women need higher educational attainments than men to: (1) become employers and (2) be in paid employment. Our results from the 
Heckman estimation indicate that men earn on average 25 percent more than women. From our Quantile regressions, we also find that these gender differences can be found throughout the income distribution but gets progressively worse towards the higher end of the distribution; men earn on average 13 percent more than women at the lower income level to 40 percent more at the upper income level.

\section{Conclusion}

This paper examines the heterogeneity in income across different occupational categories by distinguishing between employers, paid workers and self-employed own account individuals in Nigeria. The results suggest that employers experience labour wage premiums throughout the income distribution and self-employed own account individuals experience labour wage premiums at the upper quantiles, but suffer labour wage penalties at the lower quantiles compared to paid workers.

Furthermore, the results suggest that a labour wage penalty for the self-employed individuals is mainly found towards the lower end of the distribution, particularly below the threshold where paid workers enjoy a minimum wage guarantee (currently $\$ 18,000$ monthly in Nigeria). After the minimum wage effect that we find has worn-off, the labour wage differential starts to reduce steadily. We also find gender disparities in this context.

Given the context of similar low income and lower middle income countries that have minimum wage and gender characteristics like Nigeria, the paper provides some policy implications. First, since the self-employed in such countries do not receive any monetary benefits from the 
government, we agree with other authors who call for policies that create an enabling business environment for the self-employed seeing that they are clearly disadvantaged by not being guaranteed minimum wages (Van Beers, 2008; Fields, 2013).

Furthermore, the role of education in closing the gender gap is clear, as women who are highly educated have a greater probability of being employers or paid workers and thus reap the benefits of the higher incomes associated with these occupational statuses. Importantly, the results suggest that being an entrepreneur (having an occupational status as an "employer") is an important avenue for women to overcome constraints they seem to be facing in paid employment and to earn significant incomes.

As argued by Estrin et al. (2013), effective constrains on the nations executive that prevent the government from becoming predatory, are more important for value-creating entrepreneurship than lower level regulations. In this context, the paper sheds light on the potential impact of such minimum wage regulations. Given the fact that the country spends a huge amount of its oil revenue on its executive government, some of the funds could be used to reduce the costs and challenges associated with own account self-employment (Baumol, Litan, and Schramm, 2007; World Bank, 2016).

A common denominator that makes this replicable for other low income and lower middle income emerging market economies characterised by a non-transparent but non-predatory government as in the case of Nigeria, is that although self-employment may present important opportunities of value creating activities, it might be prudent to consider other ways to assure sources of decent income for individuals who cannot obtain employment that guarantees a minimum wage. 


\section{References}

Acs, Z., Åstebro, T., Audretsch, D., \& Robinson, D. T. (2016). Public policy to promote entrepreneurship: a call to arms. Small Business Economics, early view: DOI 10.1007/s11187016-9712-2.

Baumol, W. J., Litan, R. E., \& Schramm, C. J. (2007). Good capitalism, bad capitalism, and the economics of growth and prosperity. Bad Capitalism, and the Economics of Growth and Prosperity. New Haven, CT: Yale University Press.

Boden Jr, R. J. (1996). Gender and self-employment selection: An empirical assessment. The Journal of socio-economics, 25(6), 671-682.

Bosch, M., \& Maloney, W. F. (2010). Comparative analysis of labor market dynamics using Markov processes: An application to informality. Labour economics, 17(4), 621-631.

Bosma, N. S., \& Levie, J. (2010). Global entrepreneurship monitor 2009 executive report.

BritishCouncil. (2012a). Gender in Nigeria Report. Retrieved from <https://www.britishcouncil.org/partner/track-record/gender-nigeria-report-2012 > Accessed 12 May 2014.

BritishCouncil. (2012b). Gender In Nigeria Report 2012. Retrieved from <https://www.gov.uk/government/uploads/system/uploads/attachment_data/file/67333/GenderNigeria2012.pdf $>$ Accessed 3 February 2016.

Carmona, M., Congregado, E., Golpe, A. A., \& Iglesias, J. (2016). Self-employment and business cycles: Searching for asymmetries in a panel of 23 OECD countries. Journal of Business Economics and Management, 17(6), 1155-1171. 
Cunningham, W. V., \& Maloney, W. F. (2001). Heterogeneity among Mexico’s

Microenterprises: An Application of Factor and Cluster Analysis. Economic Development and Cultural Change, 50(1), 131-156.

Decker, S. (2007).Economic reforms and modernization in Nigeria, 1945-1965.African Studies Review,50(2), 268-269. DOI:10.1353/arw.2007.0089.

De Soto, H. (1989). The other path (p. 17133). New York: Harper \& Row.

DoingBusiness. (2014). Ease of Doing Business in Nigeria. Available from World Bank <http://www.doingbusiness.org/data/exploreeconomies/nigeria/>Accessed 19 February 2014.

Du, J., \& Mickiewicz, T. (2016). Subsidies, rent seeking and performance: Being young, small or private in China. Journal of Business Venturing, 31(1), 22-38.

Ehrhardt, David. "Indigeneship, Bureaucratic Discretion, and institutional change in Northern Nigeria." African Affairs (2017): 1-22.

Estrin, S., Korosteleva, J., \& Mickiewicz, T. (2013). Which institutions encourage entrepreneurial growth aspirations?. Journal of business venturing, 28(4), 564-580.

Estrin, S., Mickiewicz, T., \& Stephan, U. (2016). Human capital in social and commercial entrepreneurship. Journal of Business Venturing, 31(4), 449-467.

Fei, J. C., \& Ranis, G. (1964). Development of the labor surplus economy; theory and policy. Fields, G. S. (2013). Self-Employment in the Developing World. Paper submitted to the High Level Panel on the Post-2015 development agenda. Cornell University and Iza.

Gindling, T. (2014). Does increasing the minimum wage reduce poverty in developing countries? IZA World of Labor.

Gindling, T., \& Newhouse, D. (2014). Self-employment in the developing world. World Development, 56, 313-331. 
Gong, X., \& Van Soest, A. (2002). Wage differentials and mobility in the urban labour market: a panel data analysis for Mexico. Labour economics, 9(4), 513-529.

González-Pernía, J. L., Jung, A., \& Peña, I. (2015). Innovation-driven entrepreneurship in developing economies. Entrepreneurship \& Regional Development, 27(9-10), 555-573. doi:10.1080/08985626.2015.1075602.

Günther, I., \& Launov, A. (2012). Informal employment in developing countries: opportunity or last resort? Journal of Development Economics, 97(1), 88-98.

Harris, J. R., \& Todaro, M. P. (1970). Migration, unemployment and development: a two-sector analysis. The American Economic Review, 60(1), 126-142.

Heckman, J. J. (1979). Sample selection bias as a specification error. Econometrica: journal of the Econometric Society, 153-161.

Hughes, K. D. (2003). Pushed or Pulled? Women's Entry into Self-Employment and Small Business Ownership. Gender, Work \& Organization, 10(4), 433-454. doi: 10.1111/14680432.00205 .

Hundley, G. (2000). Male/female earnings differences in self-employment: The effects of marriage, children, and the household division of labor. Indus. \& Lab. Rel. Rev., 54, 95. Jhabvala, R., Sudarshan, R. M., \& Unni, J. (2003). Informal Economy Centrestage: New Structures of Employment: Sage.

Khanna, T., \& Palepu, K. (2013). Winning in emerging markets: A road map for strategy and execution Harvard Business Press.

Khanna, T., Palepu, K. G., \& Sinha, J. (2005). Strategies that fit emerging markets. Harvard Business Review, 83(6), 4-19. 
Koenker, Laszlo, S. (2005). Self-employment earnings and returns to education in rural Peru. Journal of Development Studies, 41(7), 1247-1287.

Lemos, S. (2009). Minimum wage effects in a developing country. Labour Economics, 16(2), 224-237.

Koenker, R., \& Hallock, K. F. (2001). Quantile regression. Journal of economic perspectives, $15(4), 143-156$.

Maloney, W. F. (2003). Informal self-employment: Poverty trap or decent alternative. Pathways Out of Poverty.(Boston: Kluwer).

Maloney, W. F. (2004). Informality revisited. World Development, 32(7), 1159-1178.

Meagher, K. (2016). Taxing Times: Taxation, Divided Societies and the Informal Economy in Northern Nigeria. The Journal of Development Studies, 1-17.

Mitra, A. (2005). Women in the urban informal sector: Perpetuation of meagre earnings. Development and Change, 36(2), 291-316.

Mohapatra, S., Rozelle, S., \& Goodhue, R. (2007). The rise of self-employment in rural China: Development or Distress? World Development, 35(1), 163-181.

NBS. (2014). Statistical Data Portal. Retrieved from Nigerian National Bureau of Statistics Nigerian National Bureau of Statistics Online Databas Portal: <http://nigeria.prognoz.com/> Accessed 20 February 2014.

National Minimum Wage Act Cap (2004). N61 Laws of the Federation of Nigeria. OECD (2014). Social Institutions and Gender Index. Retrieved from <http://www.genderindex.org/country/nigeria> Accessed 3 February 2014. 
Olarewaju, T. (2016). Linking labour force participation, education, labour wages and household consumption in developing countries: push and pull effects in self-employment-evidence from Nigeria (Doctoral dissertation, Aston University).

Palma, J. G. (2011). Homogeneous Middles vs. Heterogeneous Tails, and the End of the 'Inverted-U': It's All About the Share of the Rich. Development and Change, 42(1), 87-153.

Parker, S. C. (2009). The economics of entrepreneurship: Cambridge University Press.

Pisani, M. J., \& Pagán, J. A. (2004). Self-employment in the era of the new economic model in latin america: A case study from nicaragua. Entrepreneurship \& Regional Development, 16(4), 335-350. doi:10.1080/0898562042000263285.

Polity 4. (2017). Polity IV project:Political regime characteristics and transitions, 1800-2013. Retrieved from <http://www.systemicpeace.org/polity/polity4.htm> Accessed 10 November 2017.

Rees, H., \& Shah, A. (1986). An empirical analysis of self-employment in the UK. Journal of applied econometrics, 1(1), 95-108.

Robinson, Peter B., and Edwin A. Sexton. "The effect of education and experience on selfemployment success." Journal of Business Venturing, 9.2 (1994): 141-156.

Russ, J., Berg, C., Damania, R., Barra, A. F., Ali, R., \& Nash, J. (2017). Evaluating Transport Infrastructure Projects in Low Data Environments: An Application to Nigeria. The Journal of Development Studies, 1-20.

SLOAN. (2014). Ageing and Work: Nigeria Retrieved from <http://www.bc.edu/content/bc/research/agingandwork/archive_pubs/CP22.html> Accessed 16 November 2014.

Tamvada, J. P. (2010). Entrepreneurship and welfare. Small Business Economics, 34(1), 65-79. 
Tocqueville, Alexis de (1840/2003). Democracy in America. London: Penguin.

Uzo, U. and Mair, J. (2014), Source and Patterns of Organizational Defiance of Formal

Institutions: Insights from Nollywood, the Nigerian Movie Industry. Strategic Entrepreneurship

Journal, 8: 56-74. doi:10.1002/sej.1171.

Van Beers, C. (2008). Entrepreneurship and Economic Growth by David Audretsch, Max

Keilbach and Erik Lehmann. Development and Change, 39(1), 177-179.

Van der Sluis, J., Van Praag, M., \& Vijverberg, W. (2005). Entrepreneurship selection and

performance: A meta-analysis of the impact of education in developing economies. The World

Bank Economic Review, 19(2), 225-261.

Wellington, A. J. (2006). Self-employment: the new solution for balancing family and career?

Labour Economics, 13(3), 357-386.

Webb, J. W., Ireland, R. D. and Ketchen, D. J. (2014), Toward a Greater Understanding of

Entrepreneurship and Strategy in the Informal Economy. Strategic Entrepreneurship Journal, 8:

1-15. doi:10.1002/sej.1176.

World Bank (2015). Nigeria Overview. Retrieved from

<http://www.worldbank.org/en/country/nigeria/overview> Accessed 10 November 2015.

World Bank (2016). Nigeria. Retrieved from <http://data.worldbank.org/country/nigeria〉

Accessed 10 December 2016.

Yamada, G. (1996). Urban informal employment and self-employment in developing countries: theory and evidence. Economic Development and Cultural Change, 44(2), 289-314. 